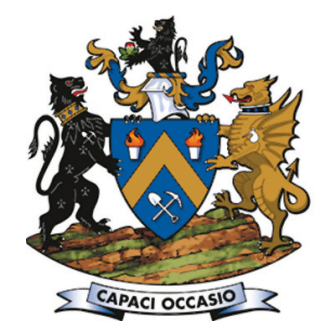

\title{
Experimental study on the stability of surrounding soft rocks of gob-side entry retaining in fully mechanized caving
}

\author{
by P.S. Zhang* †, Z.H. Kan*, W. Yan*, B. Shen*, Y.P. Zhao*, \\ and S.X. Wu*
}

\section{Synopsis}

Theoretical and field investigations were combined to analyse and determine the design parameters for a field roadway and roadside support. A gob-side entry retaining model was created with similar materials, and physical tests and numerical simulation were carried out to study the stability of surrounding soft rocks in fully mechanized caving using specific roadway and roadside supports with different stress states. The study shows that mining the upper and lower panels causes a superposition effect to the gobside entry retaining roadway, and the deformation of the surrounding rock is further exacerbated during mining of the lower panel. Moreover, the lateral residual abutment stress in the gob area could easily cause the entire roadside support to topple. A support method coupling 'long/short anchor cable plus bolts plus net' to a composite suspension beam provided excellent support for roadways with fractured roofs. As long as the roadside support strength is maintained, the secondary support provided by roof-contact yielding material will facilitate benign deformation of the roadway roof to release energy and stabilize the roadside support.

Keywords

gob-side entry retaining, similar material, simulation test stress states, fully mechanized caving, physical model. characteristics as well as control mechanisms of the roof in gob-side entry retaining of a steep thin coal seam. Tan et al. (2015) analysed the roadside support body of gobside entry retaining under the condition of hard roof. Zhang et al. (2015) analysed the application of high-water packing materials in gob-side entry retaining in a high-gas mine using numerical analysis. Yang et al. (2016) studied the soft roof failure mechanism and supporting method for a gateway in gob-side entry retaining. Yang et al. (2015) evaluated the effect of six geological factors on the design of a gob-side entry retaining structure. Han et al. (2015) combined theoretical and numerical methods to explore the stress relief and structure stability mechanism of a gobside entry retaining structure under the condition of hard roof. Li et al. (2016) investigated the fracture position of the key rock block and crack evolution processes using a gob-side filling wall by numerical modelling. These studies provided a solid theoretical foundation and technical guidance for the implementation and promotion of gob-side entry retaining technology for fully mechanized caving faces. However, due to constraints such as the testing equipment, design, and cost, only limited studies on gobside entry retaining technology for fully mechanized caving faces using similar material test methods have been conducted (Xu and Wang., 2015).
* State Key laboratory of Mining Disaster Prevention and Control co-funded by Shandong Province and Ministry of Science and Technology, Shandong University of Science and Technology, China.

+ Key Laboratory of Safe and Efficient Coal Mining Co-funded by Anhui Province and Ministry of Education, Anhui University of Science and Technology, China.

(C) The Southern African Institute of Mining and Metallurgy, 2018. ISSN 2225-6253. Paper received Feb. 2017; revised paper received Feb. 2018. 


\section{Experimental study on the stability of surrounding soft rocks of gob-side entry}

Similar material simulation testing is a conventional experimental method that is still employed in laboratory studies to resolve real-world problems using a defined mathematical model and relatively simple geological conditions. In recent years, various industries such as mining, tunnelling, and geotechnical engineering have widely adopted similar material simulation tests (Zhang et al., 2016b; Franciss., 1997; Ren et al., 2011). In this paper, a two-dimensional simulation test platform and the actual geological conditions of the 30105 working face of the Shiquan coal mine were used to design a 2D similar material test model for gob-side entry retaining. Using this model we analysed the stability of roadway surrounding rock for gobside entry retaining with different stress states. This study provides theoretical support for successful field implementation.

\section{Geological conditions and design of the entry retaining support plan}

\section{Geological conditions}

The primary coal mining layer at the 30105 working face of the Shiquan coal mine is the no. 3 coal seam. The seam is $5.05-7.20 \mathrm{~m}$ thick (average of $6.11 \mathrm{~m}$ ), the bulk density is $1.4 \mathrm{t} / \mathrm{m}^{3}$, the and the dip angle is $5-7^{\circ}$. The working face elevation is $397-535 \mathrm{~m}$ above sea level and the ground elevation is 890-954 m, hence the average depth below surface is $523 \mathrm{~m}$. The strike length and inclined length of the working face are $2236.7 \mathrm{~m}$ and $230 \mathrm{~m}$, respectively. The lithology of coal, roof, and floor is shown in Figure 1.

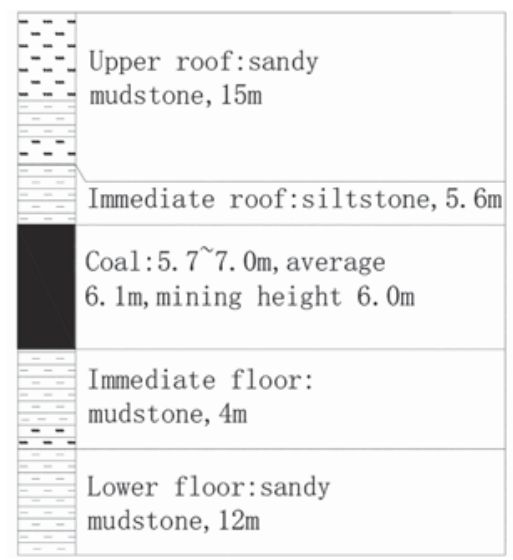

Figure 1-Lithology of coal, roof, and floor
The 30105 working face is excavated by fully mechanized coal mining methods, such as strike longwall retreat and low position full caving. Mining is based on bottom-cut-top-caving and one-cut-one-caving cyclic operations. The designed mining height is $3.0 \mathrm{~m}$, the miningcaving ratio is $1: 1$, the overall mining rate is $85 \%$, the cyclic drilling depth is $0.6 \mathrm{~m}$, and the daily advance is $2.4 \mathrm{~m}$. The layout plan of the working face is shown in Figure 2.

\section{Design of entry retaining support plan}

Roadside support is crucial for ensuring successful gob-side entry retaining. Based on research and field observations, the proposed gob-side entry retaining surrounding rock structure model (Han et al., 2015; Deng et al., 2011; Su and Hao, 2002) is shown in Figure 3. The formula used to calculate the roadside support's critical resistance is as follows:

$$
P_{f}=\left[h_{b} \gamma_{b} L_{\max }+h_{a} \gamma_{a}\left(x_{o}+c+d\right)\right] / 2
$$

where $P_{f}$ is the filling support resistance $(\mathrm{kN}), \gamma_{a}$ and $\gamma_{b}$ are the bulk densities of the immediate roof and main roof, respectively $\left(\mathrm{kN} / \mathrm{m}^{3}\right), x_{0}$ is the width of ultimate balance area in the coal mass (m), $h_{a}$ is the thickness of the immediate roof $(\mathrm{m}), h_{b}$ is the thickness of the imbalanced rock in the main roof $(\mathrm{m})$, and $L_{\max }$ is the maximum period weighting pace of the main roof $(\mathrm{m})$.

Based on the ultimate balance of the working face, the width of the ultimate balance area of the coal mass is calculated by the following formula:

$$
x_{0}=\frac{m}{2 f \xi} \ln \frac{K_{\gamma} H+c_{0} \cot \Psi_{0}}{\xi\left(c_{0} \cot \Psi_{0}+p_{1}\right.}
$$

where $c_{0}, \psi_{0}$ are the cohesion and internal friction angle respectively of the interfaces between the coal seam and the roof-floor rocks (MPa), $f$ is the interface friction factor, $p_{1}$ is the support resistance of the coal wall (MPa), $\gamma$ is the average

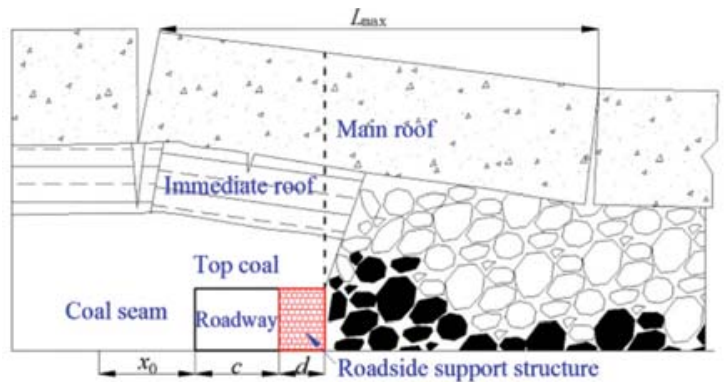

Figure 3-Simplified model of surrounding rock structure for gob-side entry retaining

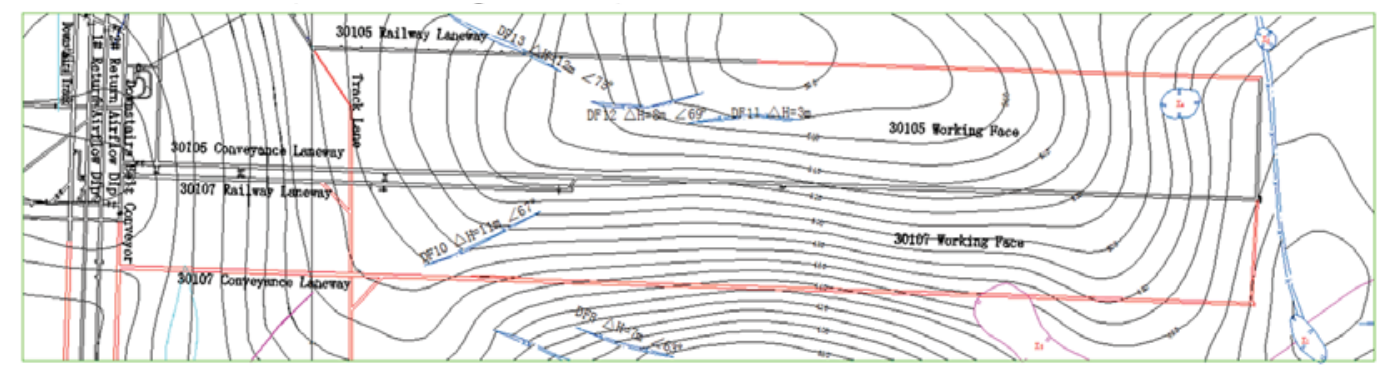

Figure 2-The layout plan of the working face 


\section{Experimental study on the stability of surrounding soft rocks of gob-side entry}

bulk density of the overlying strata $\left(\mathrm{kN} / \mathrm{m}^{3}\right), K$ is the stress concentration coefficient, $H$ is the mining depth (m), $m$ is the coal seam thickness $(\mathrm{m})$, and $\xi$ is the triaxial stress coefficient $\left(\xi=\left(1+\sin \psi_{0}\right) /\left(1-\sin \psi_{0}\right)\right)$.

The parameters of the 30105 working face are as follows: $h_{a}=5.6 \mathrm{~m}, h_{b}=25 \mathrm{~m}, L_{\max }=20 \mathrm{~m}, c=4.8 \mathrm{~m}, d=1.5 \mathrm{~m}$, $H=523 \mathrm{~m}, m=3 \mathrm{~m}, c_{0}=0.5 \mathrm{Mpa}, p_{1}=0.375 \mathrm{Mpa}, \gamma_{a}=$ $24 \frac{\mathrm{kN}}{\mathrm{m}^{3}}, \gamma_{b}=26 \frac{\mathrm{kN}}{\mathrm{m}^{3}}, \gamma=25 \frac{\mathrm{kN}}{\mathrm{m}^{3}}, \psi_{0}=25^{\circ}, f=0.3$, and $K=2$. These parameters are substituted into Equations [1] and [2] to obtain $x_{0}=4.12 \mathrm{~m}$ and the required support resistance at the initial stage of roadside filling $P_{f}=7200 \mathrm{kN} / \mathrm{m}$.

Roadside support is based on a novel concrete auto-lock entity wall (Zhang et al., 2016c), which is formed by concatenated concrete blocks of various sizes. Auto-locking between the blocks enhances the wall integrity and its resistance to lateral pressure and deformation. According to Chinese Standard GB50010-2010, the Code for Design of Concrete Structure (MHURC-PRC, 2010), the formula for calculating the bearing capability of a concrete auto-lock entity wall is as follows:

$$
N_{c u}=\varphi\left(A f_{c}+f_{y}^{\prime} A_{s}^{\prime}\right)
$$

where $N_{c u}$ is the ultimate compressive strength of the axial compression structure $(\mathrm{kN}), \varphi$ is the stability coefficient, $f_{c}$ is the concrete axial compressive strength (concrete peak stress) $(\mathrm{MPa}), f_{S}^{\prime}$ is the rebar yield strength $(\mathrm{MPa}), A$ is the structure cross-sectional area $\left(\mathrm{m}^{2}\right)$, and $A_{S}^{\prime}$ is the crosssectional area of all longitudinal compression rebars $\left(\mathrm{m}^{2}\right)$.

The parameters of a one linear metre concrete auto-lock entity wall are as follows: wall height $l_{0}=3.1 \mathrm{~m}$, wall width $d=1.5 \mathrm{~m}$, wall section short side size $b=1 \mathrm{~m}$, and $l_{0} / b=$ $3.1 / 1=3.1$. According to the specifications, $\varphi$ is equal to unity. Testing is based on a C30 concrete block with an axial compressive strength $f_{c}$ of $12.41 \mathrm{MPa}$. In each block, there are two HRB335 rebar sets $r=3 \mathrm{~mm}$, and their yield strength $f_{y}^{\prime}$ is $300 \mathrm{MPa}$. The structure's section area unit length is $A=d=1.5 \mathrm{~m}^{2}$, and $A_{S}^{\prime}=\frac{2 \pi r^{2} l_{0} d}{v}$, where $v$ is the volume of a single block $\left(1.5 \times 10^{-2} \mathrm{~m}^{3}\right)$. The calculation shows that $N_{\mathcal{C}}=23871 \mathrm{kN}$, therefore the maximum bearing capacity of a $1 \mathrm{~m}$ roadside auto-lock entity wall is $23871 \mathrm{kN}$. The theoretical calculated safety coefficient is $l=\frac{N_{\mathcal{C} u}}{P_{f}}=3.3$, which indicates that the support structure is safe.

Proper roadway support facilitates the formation of the gob-side entry retaining substructure, which is a basic condition for ensuring entry retaining stability (Bai et al., 2015). Based on actual mine production data, the roadway support plan is finally determined by theoretical calculations combined with field experience. The roadway roof support is based on the 'long/short anchor cable plus bolt plus net' coupling support method plus 'single pillar plus hinged roofbar'. Support at both sides of the roadway is based on the 'bolt plus net' method. The entry retaining support design is shown in Figure 4.

\section{Similar material simulation experiment}

\section{Physical model}

Current research findings (Li et al., 2016; Chen et al., 2012; Chen., 2012) show that the deformation of gob-side entry retaining surrounding rock in fully mechanized caving can be divided into three phases: abutment pressure in front of the upper working face, residual abutment pressure in the dip direction in the rear of the working face, and abutment pressure in front of lower working face. The direction of progress of the gob-side entry retaining working face is parallel to the entry retaining direction, which cannot be theoretically simulated in two-dimensional models. However, when spatial relationships are ignored, similar simulations of the three main deformation phases of the gob-side entry retaining surrounding rock can be performed using a twodimensional model. Based on similarity theory, the constructed model for the different phases of gob-side entry retaining is shown in Figure 5.

\section{Similar conditions}

The tests were carried out using the two-dimensional test platform of the State Key Laboratory of Mining Disaster Prevention at Shandong University of Science and Technology, China. The dimensions are as follows: $1900 \mathrm{~mm}$

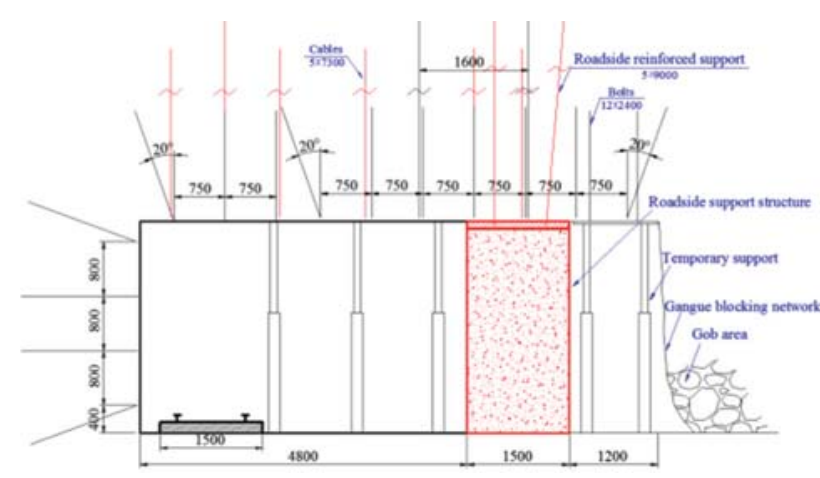

Figure 4-Entry retaining support design

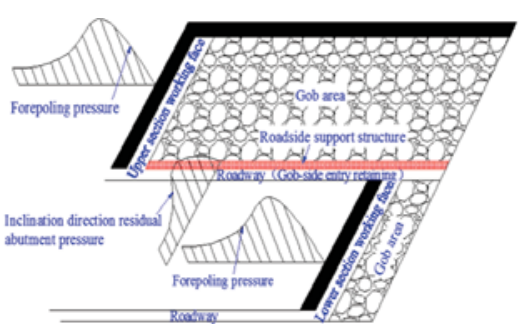

(a) Three-dimensional stress distribution model for gob-side entry retaining

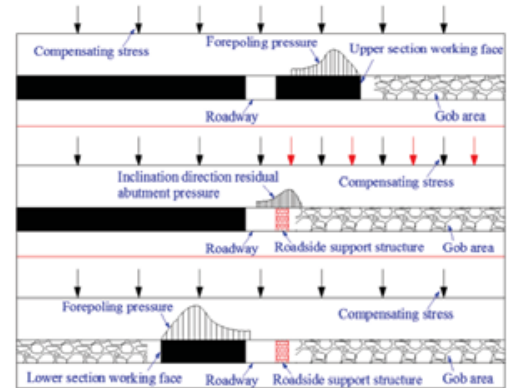

(b) Simplified stress distribution model for gob-side entry retaining based on two-dimensional similar simulations

Figure 5-Different stress influencing phases of gob-side entry retaining 


\section{Experimental study on the stability of surrounding soft rocks of gob-side entry}

(length) $\times 220 \mathrm{~mm}$ (width) $\times 1800 \mathrm{~mm}$ (height). According to the actual design for gob-side entry retaining and the actual geological data for the 30105 working face in the Shiquan coal mine, the width of the simulated gob-side entry retaining roadway is $8 \mathrm{~m}$, the height is $6 \mathrm{~m}$, and the coal thickness is $6 \mathrm{~m}$. Because the dip angle of the coal seam is shallow, the coal seam and rock strata are assumed horizontal in the model. The simulated overburden thickness is $114 \mathrm{~m}$ above the coal seam (including the coal seam thickness) and $26 \mathrm{~m}$ below the seam. The overall rock stratum height is $140 \mathrm{~m}$. Based on similarity theory (Zhang Mao, and Ma, 2002; Gu., 1995; Zhao and Zhang, 2015), the model's geometrical similarity constant is $C_{l}=\frac{l m}{l_{p}}=1: 100$ where $m$ represents the model parameter, $p$ represents the prototype parameter, and $C_{l}$ is the similarity ratio (similarly hereafter). The bulk density similarity constant is $C_{p}=\gamma_{p} \gamma_{m}=$ $1: 1.5$, the strength similarity constant of similar material (stress ratio/gravity ratio/hydro-pressure) is $C_{\sigma}=C_{l} \times C_{p}=$ 1:150, and the time similarity constant is $C_{t}=\frac{t_{m}}{t_{p}}=\sqrt{ } C_{l}=1: 10$. According to the geological data, the average density of the coal seam is $1.4 \mathrm{~g} / \mathrm{cm}^{3}$, the uniaxial compressive strength is $16 \mathrm{MPa}$, the internal friction angle is 300 degrees, and the cohesive force is $1.8 \mathrm{MPa}$. The experimental materials including sand, calcium carbonate, plaster, and water were selected to carry out the orthogonal tests in accordance with different ratios to obtain test parameters meeting the requirements of the similarity theory and experiment. The experiment coal seam has a density of $0.989 \mathrm{~g} / \mathrm{cm}^{3}$ and uniaxial compressive strength of $0.075 \mathrm{MPa}$. Parameters for the other strata are shown in Table I. The anchor cable was simulated by an aluminum wire $1.8 \mathrm{~mm}$ in diameter with a $65 \mathrm{~N}$ tensional strength, and the bolt was simulated by an aluminum wire $1.5 \mathrm{~mm}$ in diameter with a $55 \mathrm{~N}$ tensional strength. Because of the constraints of the testing conditions, providing anchor cable support during entry excavation is difficult. To facilitate operations during testing, anchor cables are laid in position in advance as designed using similarity theory.

\section{Deployment of the measurement points}

To study the influence of the abutment pressure in front of the upper working face, the residual abutment pressure in the dip direction in the rear of working face, and the abutment pressure in front of the lower working face on the stability of the roadway surrounding rock, 14 stress sensors are deployed in this simulation. The sensor measurement points $\mathrm{S}_{1}-\mathrm{S}_{4}$ are located in the upper working face coal seam roof within a certain distance from the roadway section, and the horizontal spacing between measurement points is always $8 \mathrm{~m}$. Measurement points $\mathrm{S}_{5}-\mathrm{S}_{7}$ are located in the rock stratum within $2 \mathrm{~m}$ of the roadway roof, and the horizontal spacing between the measurement points is

$4.75 \mathrm{~m} . \mathrm{S}_{6}$ is located in the centre line of the roadway roof. Measurement points $S_{8}-S_{11}$ are located at the lower working face coal seam roof within a certain distance from the roadway section, and the horizontal spacing between measurement points is always $8 \mathrm{~m}$. Measurement points $\mathrm{S}_{12}$ $\mathrm{S}_{14}$ are located in the rock stratum within $2 \mathrm{~m}$ of the roadway floor, and the horizontal spacing between measurement points is $4.75 \mathrm{~m} . \mathrm{S}_{13}$ is located in the centre line of the roadway floor. A detailed measurement point layout is shown in Figure 6.

To study the surrounding rock deformation at different phases throughout the entire gob-side entry retaining process, nine displacement measurement points are deployed around the roadway. Points $D_{1}-D_{3}$ are located in the rock stratum within $1 \mathrm{~m}$ of the roadway roof, and the horizontal spacing between measurement points is $3 \mathrm{~m} . \mathrm{D}_{2}$ is located in the centre line of the roadway roof. $\mathrm{D}_{4}-\mathrm{D}_{6}$ are located in the rock stratum within $1 \mathrm{~m}$ of the roadway floor, and the horizontal spacing between measurement points is $3 \mathrm{~m} . \mathrm{D}_{5}$ is located in the centre line of the roadway floor. $\mathrm{D}_{7}$ and $\mathrm{D}_{8}$ are located at the $1 \mathrm{~m}$ deep coal seam on each side of the roadway. After mining of the upper working face is completed, measurement point $\mathrm{D}_{7}$ replaces measurement point $\mathrm{D}_{7}$. Displacement is monitored using the total station method. A detailed layout of the measurement points is shown in Figure 7.

Table I

Parameters of different strata

\begin{tabular}{|c|c|c|c|c|c|c|c|c|}
\hline \multirow[t]{2}{*}{ Lithology } & \multirow{2}{*}{$\begin{array}{l}\text { Thickness of stratification } \\
\text { for model }(\mathrm{cm})\end{array}$} & \multirow{2}{*}{$\begin{array}{l}\text { Cumulative } \\
\text { height }(\mathrm{cm})\end{array}$} & \multirow{2}{*}{$\begin{array}{l}\text { Ratior } \\
\text { numbe }\end{array}$} & \multirow{2}{*}{$\begin{array}{c}\text { Bulk density } \\
\mathrm{g} / \mathrm{cm}^{3}\end{array}$} & \multicolumn{4}{|c|}{ Material dosage (kg) } \\
\hline & & & & & Sand & Calcium carbonate & Plaster & Water \\
\hline Fine sandstone & 6 & 131 & 782 & 1.6 & 45.65 & 5.22 & 1.30 & 5.22 \\
\hline Siltstone & 21 & 116 & 755 & 1.6 & 159.76 & 11.41 & 11.41 & 18.26 \\
\hline Coal & 6 & 32 & 864 & 1.35 & 39.12 & 2.93 & 1.96 & 4.40 \\
\hline Mudstone & 1 & 6 & 864 & 1.5 & 7.25 & 0.54 & 0.36 & 0.82 \\
\hline Sandy mudstone & 5 & 5 & 864 & 1.6 & 38.64 & 2.90 & 1.93 & 4.35 \\
\hline
\end{tabular}

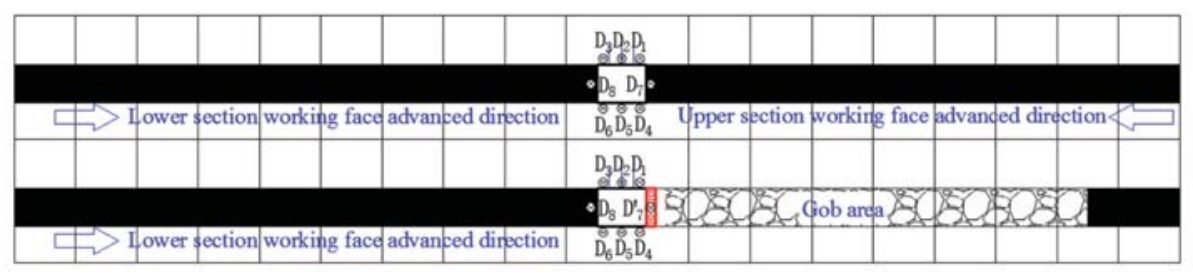

Figure 6-Layout of the stress measurement points 


\section{Experimental study on the stability of surrounding soft rocks of gob-side entry}

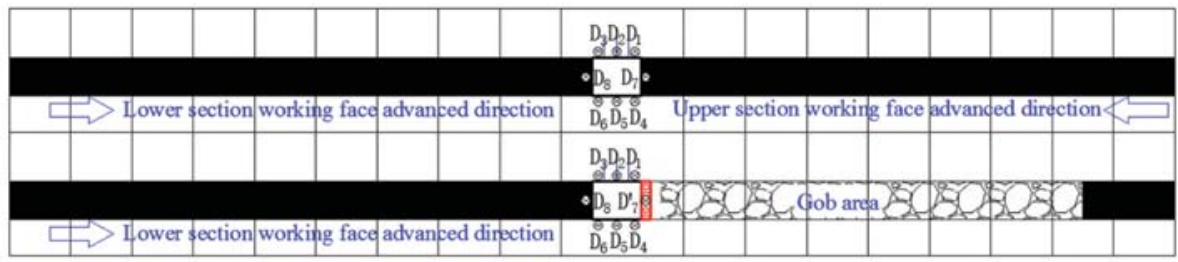

Figure 7-Layout of the displacement measurement points

\section{Mining design}

In the test model, roadway development is completed before the upper working face is mined. Subsequently, bolt support for the roadway is deployed in a similar configuration. At each side of the model, a $15 \mathrm{~m}$ boundary coal pillar is left. The working face moves from the model boundary towards the roadway. After mining of the upper working face is completed, the suspension roof at the roadside support is immediately reinforced. Next, a roadside support structure with dimensions of $220 \mathrm{~mm}$ (length) $\times 60 \mathrm{~mm}$ (height) $\times$ $15 \mathrm{~mm}$ (width), which was pre-arranged to provide a similar strength, is filled at the roadside, and the roof-contact yielding material (plastic foam with dimensions of $220 \mathrm{~mm}$ (length) $\times 5 \mathrm{~mm}$ (height) $\times 15 \mathrm{~mm}$ (width)) is applied at the support roof to simulate actual roof-contact yielding material (wooden pillar, Figure 8). After the support is in place, the model is loaded under stress for 1-2 days to simulate roadway and roadside support deformation caused by residual abutment pressure in an inclined direction in the rear of working face. The final step is mining of the lower working face. In the model, the mining height is $6 \mathrm{~cm}$, which is equivalent to the actual mining height of $6 \mathrm{~m}$, and the mining progresses at $2.4 \mathrm{~cm}$ in intervals of 1 hour, which is equivalent to the $2.4 \mathrm{~m}$ progress that occurs each day.

\section{Analysis of the test results}

\section{Influencing phase of abutment pressure in front of upper section working face}

For the upper working section, the vertical stress variation in the roadway roof and floor as well as the coal seam roof is shown in Figure 9. The displacement variation curve for the roadway surrounding rock is shown in Figure 10.

Figure 9a shows that with continuous progress of the working face, the stress on the coal seam roof always

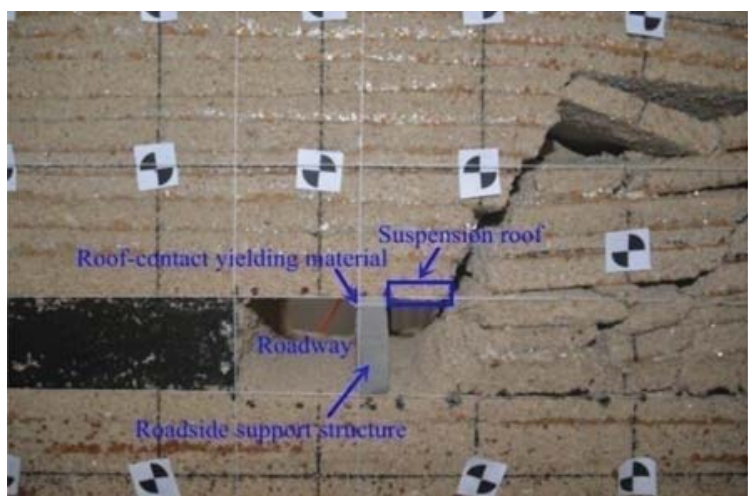

Figure 8-Simulation test for roadside support

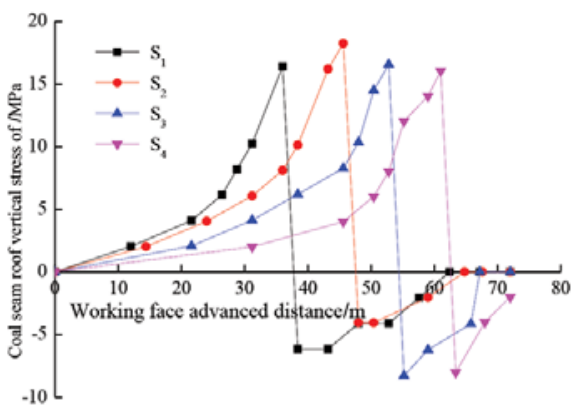

(a) Coal seam roof stress variation

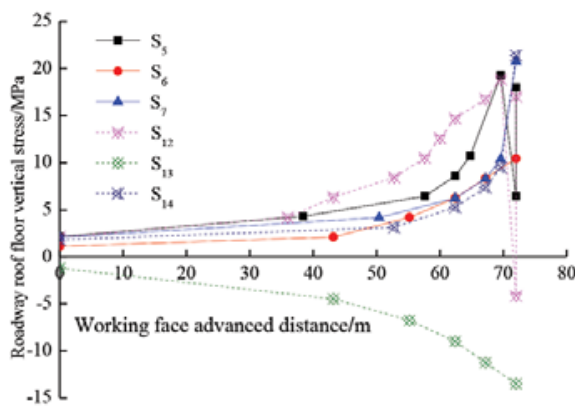

(b) Roadway roof floor stress variation

Figure 9-Stress variation - upper section working face

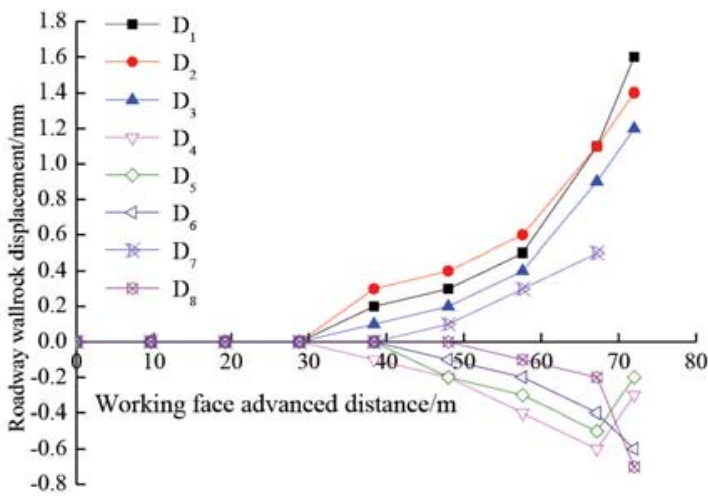

Figure 10-Displacement variation in roadway surrounding rock upper section working face

increases at the initial stage and then decreases. Moreover, prior to the working face reaching a measurement point, the magnitude of variation is larger at points closer to the working face. Variations are observed at measurement points $\mathrm{S}_{1}, \mathrm{~S}_{2}, \mathrm{~S}_{3}$, and $\mathrm{S}_{4}$ when the working face progresses to $12 \mathrm{~m}$, $14.4 \mathrm{~m}, 21.6 \mathrm{~m}$, and $31.2 \mathrm{~m}$, respectively, and when the working face progresses to $36 \mathrm{~m}, 45.6 \mathrm{~m}, 52.8 \mathrm{~m}$, and $61 \mathrm{~m}$, respectively, the stress reaches its peak. When the working face passes the measurement point, the stress at the measurement point changes to a negative value, and the 


\section{Experimental study on the stability of surrounding soft rocks of gob-side entry}

measurement point becomes invalid. Based on the stress variation trend for measurement points $\mathrm{S}_{1}-\mathrm{S}_{4}$, the analysis shows that the abutment pressure is effective within $33 \mathrm{~m}$ in front of the working face. In addition, the peak value of abutment pressure is located in 2-3 $\mathrm{m}$ in front of the working face, where the peak values are within the range of 16$18 \mathrm{MPa}$.

Figure $9 \mathrm{~b}$ shows that the roadway roof and floor stress increase with the progress of the working face, and after the stress values at the measurement points $S_{5}$ and $S_{12}$ reach peak values, they undergo a sharp decrease and then increase again. The initial stress values at the measurement points $\mathrm{S}_{5}, \mathrm{~S}_{6}$, and $\mathrm{S}_{7}$ are $2.15 \mathrm{MPa}, 1.1 \mathrm{MPa}$, and $2.08 \mathrm{MPa}$, respectively. Because the measurement points $S_{5}$ and $S_{7}$ are located at both sides of the roadway roof and measurement point $S_{6}$ is located in the centre line of the roadway roof, the concentrated stress accumulates at both sides of the roadway roof after roadway excavation is completed, which leads to an increase in stress at measurement points $S_{5}$ and $S_{7}$ before the working face and a relatively small stress of $1.1 \mathrm{MPa}$ at the roadway roof measurement point $\mathrm{S}_{6}$. The stresses at measurement points $S_{5}, S_{6}$, and $S_{7}$ reach peak values of 19.3, 10.4 , and $20.7 \mathrm{MPa}$ when the working face progresses to $69.6 \mathrm{~m}, 72 \mathrm{~m}$, and $72 \mathrm{~m}$, respectively. The peak stress at measurement point $\mathrm{S} 6$ is relatively small because when the roadway is under abutment pressure in front of the working face, the roadway roof begins to sink and releases energy. When the working face passes measurement point $S_{5}$, measurement point $S_{5}$ still bears pressure because of the effect of the immediate suspension roof; however, the stress decreases to 6.4 $\mathrm{MPa}$. The initial stress values at measurement points $\mathrm{S}_{12}, \mathrm{~S}_{13}$, and $\mathrm{S}_{14}$ are $2.1,-1.2$, and 1.8 $\mathrm{MPa}$, respectively. Measurement point $\mathrm{S}_{13}$ is under reducing stress, and the value is negative. The cause of the differences in the initial stress values is similar to the cause of the differences at the roadway roof measurement points $S_{5}, S_{6}$, and $S_{7}$. The stress values at measurement points $S_{12}, S_{13}$, and $\mathrm{S}_{14}$ reach peak values of $18.9 \mathrm{MPa},-13.5 \mathrm{MPa}$, and 21.4 MPa when the working face progresses to $69.6 \mathrm{~m}, 72 \mathrm{~m}$, and $72 \mathrm{~m}$, respectively. Because of significant roadway floor deformation, rock at $S_{13}$ releases energy, which results in a relatively small stress. When the working face progresses to $72 \mathrm{~m}$, the gob area and roadway are connected. Because of the effect of roadway support, the roadway roof can resist deformation to a certain degree. Long suspension roof spans lead to higher peak stress values at measurement point $S_{14}$ than at measurement point $S_{12}$. The stress values at measurement points $S_{5}$ and $S_{12}$ decline sharply, and after the roadside support is completed, the stress values at measurement points $S_{5}$ and $S_{12}$ rise sharply.

Figure 10 shows that before the working face progresses to $38.4 \mathrm{~m}$, the deformation of the roadway surrounding rock is zero. When the face reaches $38.4 \mathrm{~m}$, the roadway surrounding rock starts to displace. As the working face progresses further, the displacement gradually increases, and after measurement points $D_{4}$ and $D_{5}$ reach peak values, the displacements then decrease. Before the working face progresses to $72 \mathrm{~m}$, among all roadway roof measurement points, measurement point $\mathrm{D}_{2}$ shows the largest reduction, and measurement point $\mathrm{D}_{3}$ the smallest. When the working face progresses to $72 \mathrm{~m}$, measurement point $\mathrm{D}_{1}$ shows the largest reduction, because before the working face progresses to $72 \mathrm{~m}$, measurement points $\mathrm{D}_{1}$ and $\mathrm{D}_{3}$ are affected by roadway support on both sides, and they show a smaller reduction than measurement point $\mathrm{D}_{2}$. When the working face progresses to $72 \mathrm{~m}$, the right side of the roadway loses support, and the stress reduction at measurement point $\mathrm{D}_{1}$ increases instantaneously. The roadway floor has a smaller displacement than the roof, and measurement point $\mathrm{D}_{4}$ shows the largest displacement, while measurement point $\mathrm{D}_{6}$ shows the smallest. When the working face progresses to $72 \mathrm{~m}$, the right side of the roadway has a developed gob, and the roof fails to reach the floor, which leads to decreases in the displacement at the floor at measurement points $\mathrm{D}_{5}$ and $\mathrm{D}_{6}$. The displacement values at measurement points $\mathrm{D}_{7}$ and $\mathrm{D}_{8}$ at both sides of the roadway increase gradually with the progress of the working face, and the rate accelerates. Overall, the primary mining-induced deformation of the roadway surrounding rock is relatively small, which facilitates roadway maintenance in the stable phase of entry retaining.

\section{Influencing phase of residual abutment pressure in inclination direction in the rear of working face}

After the upper working face is completed, the residual abutment pressure from the gob area is readjusted. The stress variation in the roadway roof and floor that occurs over time as the working face progresses further is shown in Figure 11 The roadway displacement curve is shown in Figure 12.

Figure 11 shows that after the upper working face is completed, the residual abutment pressure is adjusted. Over time, the stress in the roadway surrounding rock increases and eventually stabilizes. Among the roof measurement points $S_{5}-S_{7}$, measurement point $S_{5}$ has the most significant stress increment and measurement point $S_{6}$ the least. Measurement point $S_{5}$ is located in the roof rock immediately above the support structure and receives the most influence from the residual abutment pressure of the gob area, which leads to a significant stress increment. Measurement point $\mathrm{S}_{6}$, in the centre line of the roadway roof, develops a relatively large deformation and releases energy, which leads to relatively small stress variations. Among the roadway floor stress measurement points $S_{12}-S_{14}$, measurement point $S_{12}$ has the most significant stress increment (similar to measurement point $\mathrm{S}_{5}$ ), measurement point $\mathrm{S}_{13}$ has the least significant stress increment (similar to measurement point $\mathrm{S}_{6}$ ), and measurement point $\mathrm{S}_{14}$ is affected by concentrated

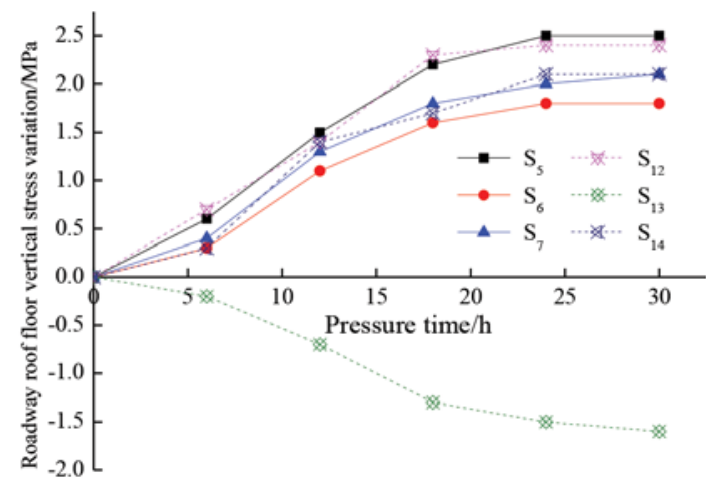

Figure 11-Stress variation in roadway roof and floor - residual abutment pressure 


\section{Experimental study on the stability of surrounding soft rocks of gob-side entry}

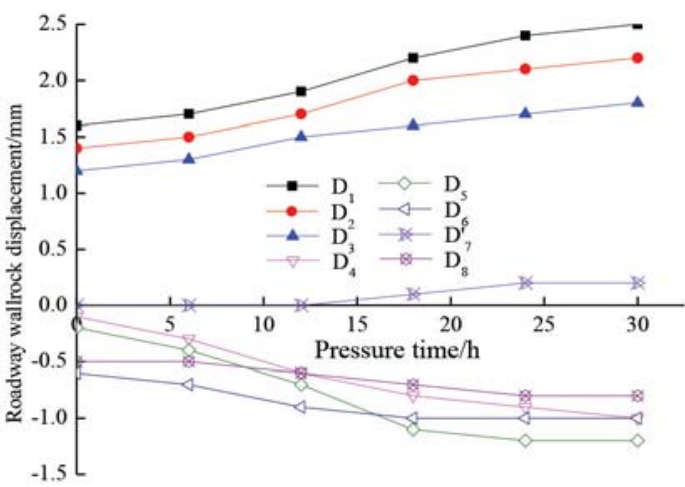

Figure 12-Displacement variation in roadway surrounding rock residual abutment pressure

stress from the coal wall at the left side of the roadway. The stress at this point gradually increases and eventually stabilizes.

Figure 12 shows that after the upper working face is completed, the lateral residual abutment pressure in the gob area results in roadway deformation. Over time, the deformation rate stabilizes. Among all of the roadway roof measurement points $\mathrm{D}_{1} \sim \mathrm{D}_{3}$, measurement point $\mathrm{D}_{1}$ has the largest reduction in displacement and measurement point $\mathrm{D}_{3}$ the smallest. Because measurement point $D_{1}$ is the closest to the roadside support structure, the roadside roof-contact yielding material is affected by the concentration load of the overlying strata and begins to deform, which leads to the largest deformation at measurement point $\mathrm{D}_{1}$. Measurement point $D_{3}$ is located above the left side coal wall, and because of the support of the roadway coal wall, has the smallest deformation. The floor heave at the roadway floor measurement points $\mathrm{D}_{4}-\mathrm{D}_{6}$ increases over time, and measurement point $\mathrm{D}_{5}$ has the largest final floor heave. The displacements at points $\mathrm{D}_{7}-\mathrm{D}_{8}$ at both sides of the roadway also increase gradually over time. However, because of the high rock strength of the roadside block, the displacement at measurement point $\mathrm{D}_{7}$ is relatively small and primarily manifested as a tilting of the entire support structure toward the roadway. In contrast, the coal wall is at the left side, and has a lower strength. Affected by the concentrated stress on the coal wall, measurement point $\mathrm{D}_{8}$ has a larger relative displacement. The roadway deformation during this phase increases over time and eventually stabilizes. However, the variations are relatively small and do not have an impact on lower working face mining.

\section{Influencing phase of abutment pressure in front of lower working face}

The vertical stress variation in the roadway roof and floor as well as the coal seam roof during mining of the lower working face is shown in Figure 13. The roadway displacement variation curve is shown in Figure 14.

A comparison of Figure 13 and Figure 9 shows that during the lower mining phase, the stress variation trend in the coal seam roof and roadway roof /floor is the same as that during the upper mining phase. Based on the stress variation trend at measurement points $\mathrm{S}_{8}-\mathrm{S}_{11}$, the analysis shows that the influencing zone of abutment pressure is within $35 \mathrm{~m}$ of the front of the lower working, the peak value

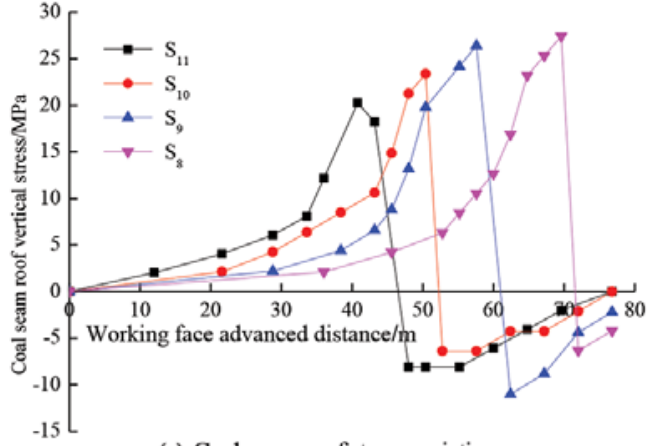

(a) Coal seam roof stress variation

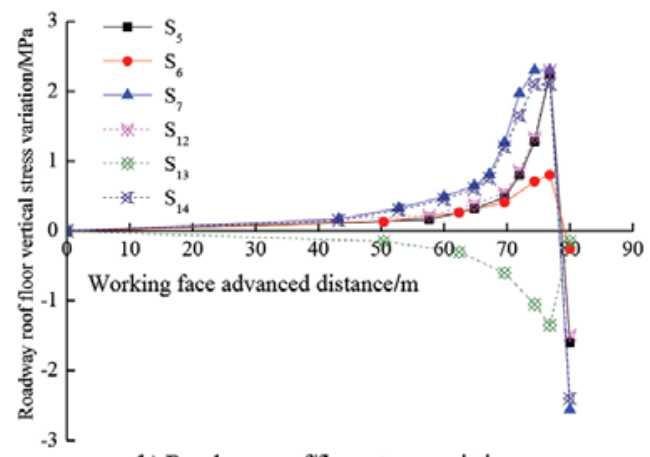

(b) Roadway roof/floor stress variation

Figure 13-Stress variation - lower working face

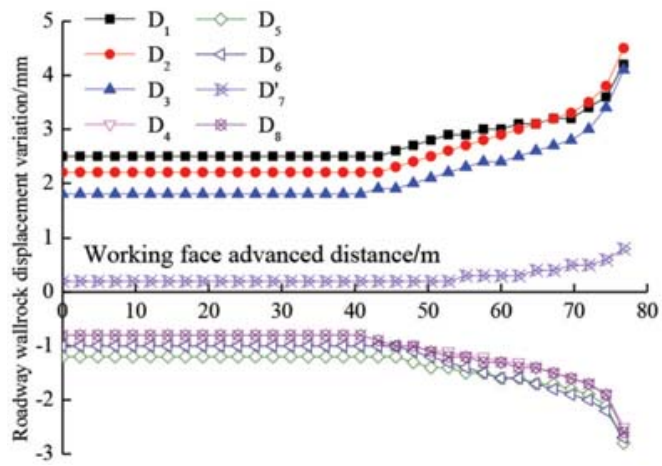

Figure 14-Displacement variation in roadway surrounding rock - lower working face

of abutment pressure is located in 4-5 $\mathrm{m}$ in front of the working face, and the maximum stress is larger than the maximum stress at the upper section coal seam roof. With increased testing time, the moisture content of the simulated rock changes accordingly, resulting in variations of the zone of influence of the abutment pressure, peak stress area, and span of the roof cantilever. Figure 13b shows that the stress in the roadway roof and floor increases as the lower working face progresses further. Affected by abutment pressure, the stress variation rate accelerates and the stress reaches a peak when the working face progresses to approximately $76.8 \mathrm{~m}$. Subsequently, the roadway develops a significant deformation and the stress decreases sharply.

Figure 14 shows that as the lower working face progresses, deformation of the roadway surrounding rock is initially stable. When the working face progresses to $43.2 \mathrm{~m}$, the surrounding rock deformation starts to accelerate. When the working face progresses to approximately $76.8 \mathrm{~m}$, the peak abutment pressure has an effect on the roadway. At this 


\section{Experimental study on the stability of surrounding soft rocks of gob-side entry}

moment, the roadway deformation rate reaches its peak. Because of the high strength of the roadside support structure, the deformation is relatively small and primarily takes the form of tilting of the entire structure. Overall, the deformation of the entire roadway is significant. However, the roadway still satisfies the requirement for lower working face mining.

After the lower working is completed, the reserved upper roadway will no longer be used. The roadway is located in the gob area and develops a significant deformation, as shown in Figure 15.

Figure 15 shows photographs of the surrounding rock deformation after the entry retaining structure is abandoned. The roadway roof and floor and two sides show significant deformation, and the roof anchor cable is exposed. The roadside support structure undergoes a relatively small actual deformation during the tilting of the entire structure. Therefore, in field implementations, measures should be taken to reinforce the integrity and anti-toppling capability of the roadside support structure.

\section{Numerical model verification}

FLAC3D (Itasca, 2009), is selected as the computing software. The total size of the model is $505 \mathrm{~m} \times 192 \mathrm{~m} \times$ $79 \mathrm{~m}$, with $52 \mathrm{~m}$ roof thickness of coal seam and $27 \mathrm{~m}$ floor thickness of coal seam (including the coal seam). The model is divided into 560400 basic units and 605772 grid nodes. The burial depth of the coal seam is $523 \mathrm{~m}$, and the thickness is $6 \mathrm{~m}$. The coal seam is set horizontal due to the small actual dip angle. The working face is $220 \mathrm{~m}$ long. The size for gobside entry retaining is rectangular with a cross-section of $5 \mathrm{~m}$ $\times 3 \mathrm{~m}$. Because the paper focuses on the influence of mining in the upper and lower panels on the confining pressure of gob-side entry retaining, the grids at the location of gob-side entry retaining, which is the main research area, are finer. The initial model is shown in Figure 16.
The horizontal displacement constraints are set around the model, and the fix constraint is set on the base. The upper interface is a stress boundary, whose load is determined by the load imparted by the overlying strata $(\mathrm{Bu}$ and Mao, 2009). The caving mining method is used to manage the roof, and the Mohr-Coulomb model is simulated. The lithology parameters are shown in Table II.

To analyse the displacement and stress variation in the surrounding rock of the retained roadway during mining of the upper and lower sections, the displacement measuring points $\mathrm{D}_{1}-\mathrm{D}_{4}$ are set respectively in the roadway roof, floor,

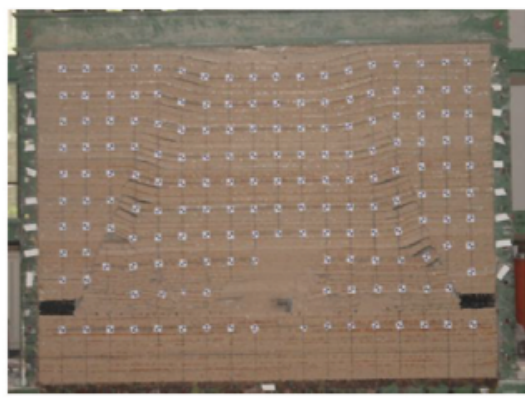

(a) Overall model diagram

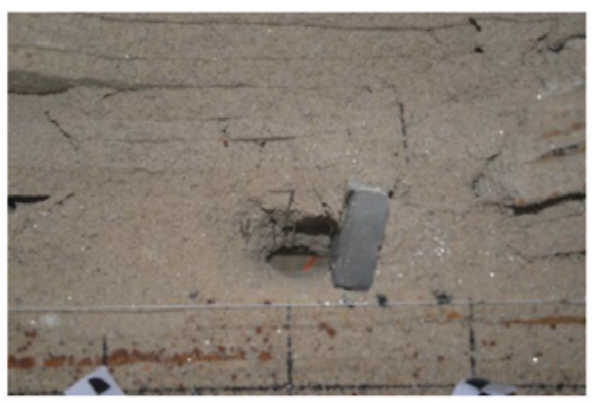

(b) Partial defomation of the entry retaining surrounding rock

Figure 15-Photographs showing the entry retaining surrounding rock
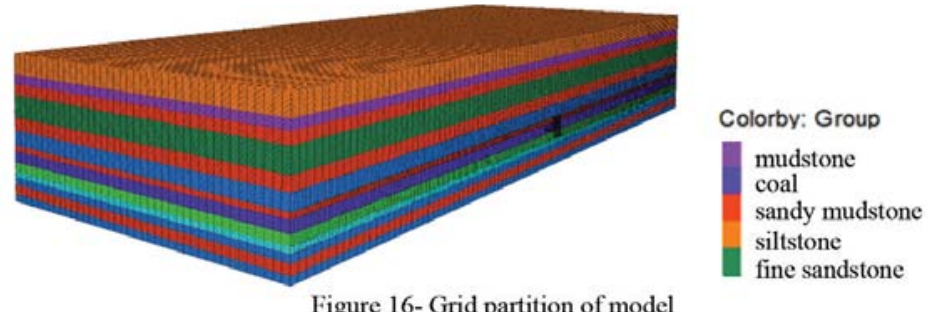

Figure 16-Grid partition of model

Table II

Physical and mechanical parameters of rock mass

\begin{tabular}{|c|c|c|c|c|c|c|}
\hline Lithology & Bulk modulus (MPa) & Shear modulus (GPa) & Bulk density (kg.m-3) & Cohesion (MPa) & Internal friction angle $\left({ }^{\circ}\right)$ & Tensile strength (GPa) \\
\hline Siltstone & 4 & 3 & 2550 & 3.5 & 33 & 2.2 \\
\hline Mudstone & 2.8 & 1.9 & 2200 & 3.4 & 32 & 1.8 \\
\hline Sandy mudstone & 3.6 & 2.9 & 2450 & 2.35 & 32 & 1.32 \\
\hline Fine sandstone & 3.3 & 2.4 & 2600 & 8.2 & 32 & 2.8 \\
\hline Coal & 1.8 & 1.4 & 1420 & 1.8 & 30 & 0.9 \\
\hline Roadside support & 3.0 & 2.2 & 2700 & 6.2 & 30 & 2.1 \\
\hline
\end{tabular}




\section{Experimental study on the stability of surrounding soft rocks of gob-side entry}

and midpoints of two sides. The stress points $S_{1}$ and $S_{2}$ are set at $4 \mathrm{~m}$ on left side of the roadway and in the roadside support structures on the right. The displacement and stress measuring lines are set in the strata $1 \mathrm{~m}$ from the roadway roof as well as the floor. The layout of the measuring points is shown in Figure 17.

Figure 18 shows the rock stress variation on two sides of retained roadway with the advance of the working face during mining of the upper section.

From Figure 18, stresses at measuring point $S_{1}$ and $S_{2}$ increase as the working face advances. However, stress at point $S_{2}$ increases dramatically before caving of the overlying strata of gob, and then increases slowly after periodic caving of the overlying strata of gob with further advance of the working face.

Figure 19 shows the displacement variation of the rock surrounding the retained roadway as the working face advances. The vertical displacement at measuring point $D_{1}$ and the horizontal displacement at measuring point $\mathrm{D}_{3}$ increase continuously as the face advances, but the variation of the vertical displacement is larger than that of the horizontal displacement. The vertical displacement at measuring point $\mathrm{D}_{2}$ and the horizontal displacement at measuring point $\mathrm{D}_{4}$ vary slightly initially, but when the working face advances a certain distance, the variation increases sharply, and then as the working face continues to advance, the vertical displacement at $\mathrm{D}_{2}$ decreases, that is, floor heave diminishes, while the horizontal displacement at $\mathrm{D}_{4}$ increases inversely in a narrow range.

Figures 20 and 21 respectively describe the displacement and stress in the roadway roof and floor in the measurement lines. Figure 20 shows that the vertical displacements of

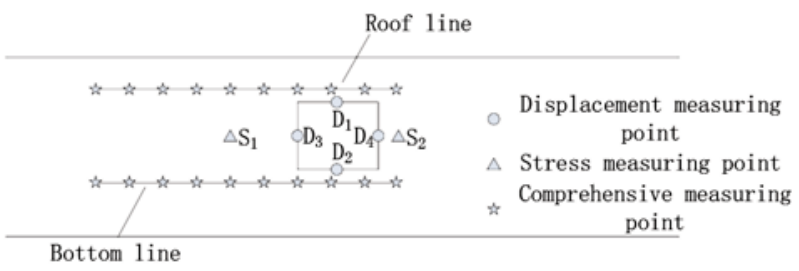

Figure 17-Layout of measuring points around roadway

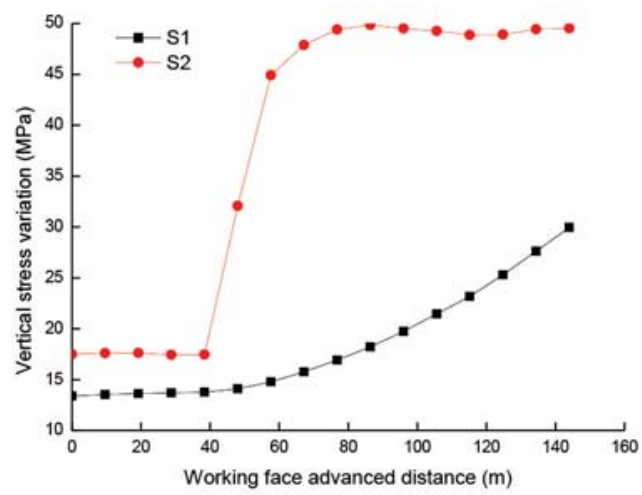

Figure 18-Stress variation - retained roadway sides

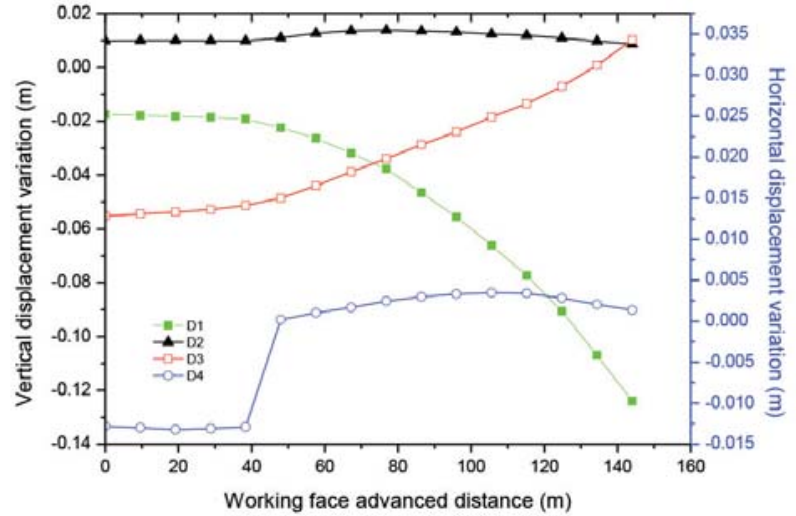

Figure 19-Displacement variation - retained roadway sides

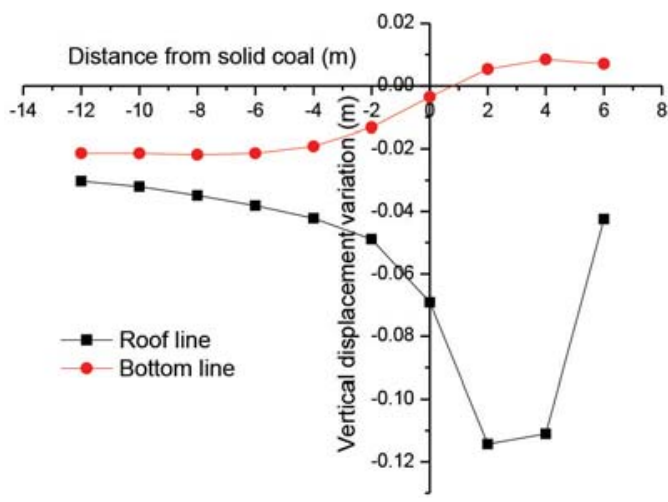

Figure 20-Displacement variation - roadway roof and floor

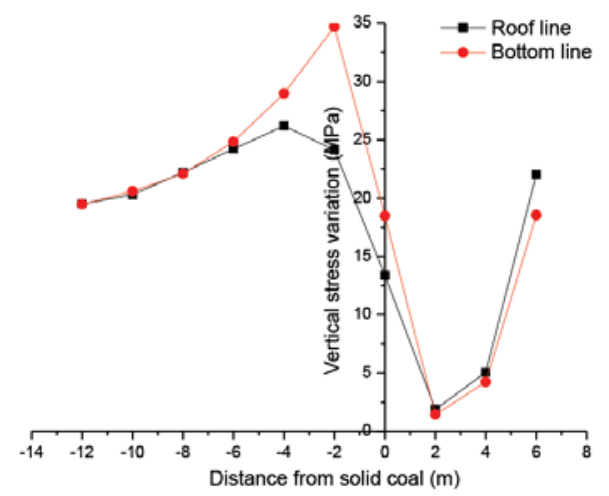

Figure 21-Stress variation - roadway roof and floor

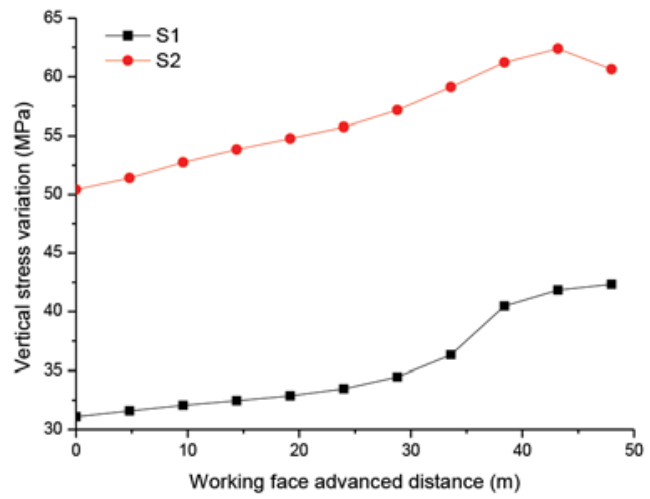

Figure 22-Stress variation - retained roadway sides 


\section{Experimental study on the stability of surrounding soft rocks of gob-side entry}

measuring points on the coal wall decrease with increasing distance from the roadway axis, and the roof subsidence displacement is larger than floor heave displacement, which is supported by the stress variation shown in Figure 21. Figure 21 shows that the stress concentrates on both sides of roadway, while the stress in the roof and floor releases due to the excavation.

The variation of in stress and displacement on both sides of the retained roadway during mining of the lower panel, are shown in Figures 22 and 23.

Figure 22 shows that the roof and floor stresses increase as the working face advances in the pre-influencing phase of mining of the lower section, which is consistent with the trends shown in Figure 18. From Figure 23, the vertical displacement of the roof measuring points D1 and the floor measuring points $\mathrm{D}_{2}$, as well as the horizontal displacement

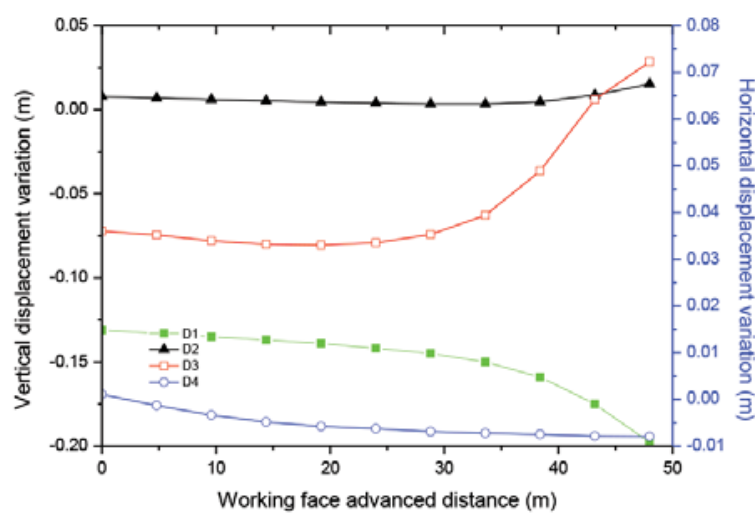

Figure 23-Displacement variation - retained roadway sides of measuring point $\mathrm{D}_{3}$, all increase with advance of the working face. The variation in vertical displacement is larger than that of horizontal displacement; but the horizontal displacement at measuring point $\mathrm{D}_{4}$ on the side of the roadside support changes as mining progresses, indicating the instability of the roadside support. This is corroborated by the failure of the roadside support (Figure 13).

The distribution of the plastic zone of the surrounding rock in the retained roadway and the actual field observation as the upper and lower working faces are mined are shown in Figures 24 and 25 respectively.

From Figure 24a, mining of the upper section has an effect on roadside support, leading to damage in the upper plastic zone, but the support is stable overall and is very

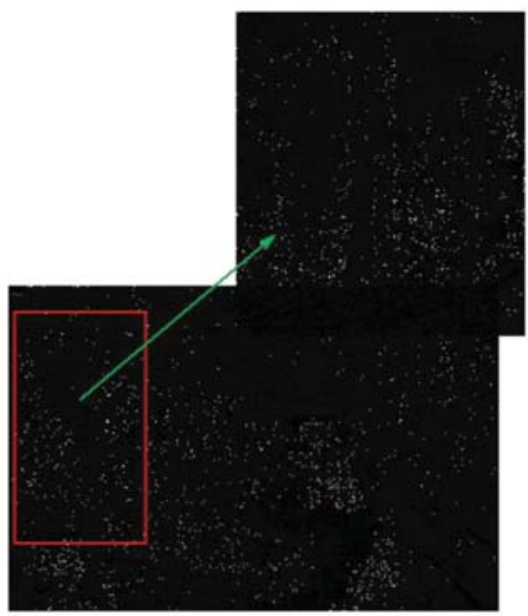

Figure 25-Field observation of retained roadway

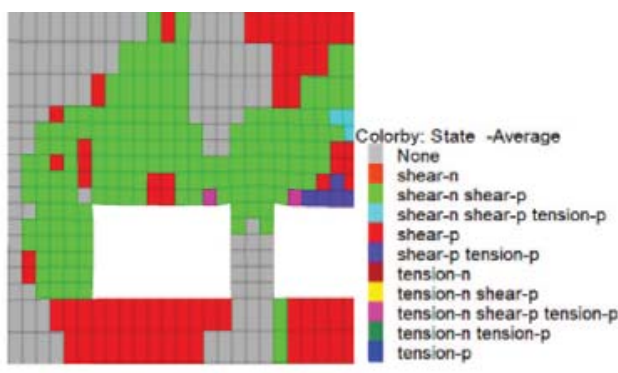

(a) The upper section mining

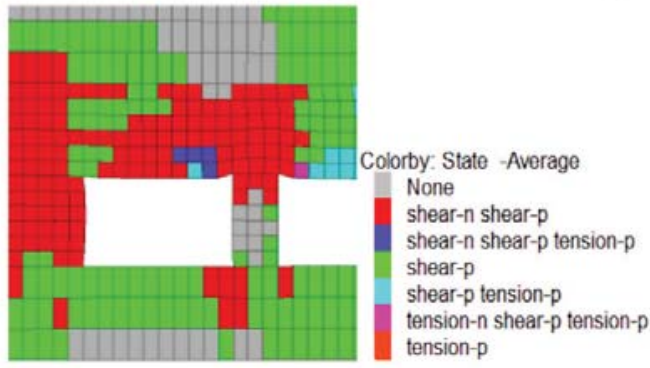

(b) The lower section mining 


\section{Experimental study on the stability of surrounding soft rocks of gob-side entry}

effective, as verified by the similar material test (Figure 8) and the engineering application (Figure 25). Mining of the lower section has a more serious effect on roadside support (Figure 24b), and plastic zones form on the top and bottom of the roadside support, increasing the instability, which is again consistent with the failure of the roadside support (Figure 13).

\section{Discussion of the method}

The similar material simulation test is based on the similarity theory proposed by Kuznetsov, and is an experimental research method leading from physical testing, mechanical analysis, and model testing to a practical engineering guide (Qian et al.,1958; Li., 1988). It is widely used in such industries as mining, water conservancy, and underground engineering, and is a mainstream research method in natural science and engineering technology (Cheng, Qi, and Hong,2016; Gong, Hu, and Zhao, 2005; Liu, Cai, and Zhou, 2015; Shi, Zhang, and Li, 2011; Yao, Feng, and Liao, 2017). With the rapid development of computerized methods in rock mechanics, much experimental work has been replaced by numerical simulation (Zhang, 1999; Zhang et al., 2016b; Wang, Zhang, and Gao, 2015). Meanwhile, the traditional point-measurement method, which takes points as the basic measuring locations (Yao, Feng, and Liao, 2017) is still used in the similar material simulation test, but suffers from low measurement accuracy and difficulty in stress measurement as well as displacement in the internal part of model, which may be solved in the future by optical fibre sensing technology that can offer measurement along lines (Chai, Wang, and Liu, 2015; Cornelia and Marcel, 2003; Yang, Bhalla, and Wang, 2007). As one of the experimental rock mechanics methods, however, the similar material simulation test is still widely used in the study of coal mining, which has incomparable advantages in the field of a wider range of rock caving and movement than numerical simulation ( $\mathrm{Luo}, \mathrm{Wu}$, and Liu, 2016; Fan, Mao, and $\mathrm{Xu}, 2016$; $\mathrm{Wu}, \mathrm{Xie}$, and Wang,2010).

\section{Conclusions}

Based on detailed geological conditions and field design plans, a similar material simulation experiment and numerical simulation were performed to study the stress and deformation variations of the roadway surrounding rock at different states of gob-side entry retaining in fully mechanized caving. The following conclusions can be drawn.

(1) Roadway surrounding rock of gob-side entry retaining in fully mechanized caving has three critical influencing phases: the phase of abutment pressure in front of the upper working face, the phase of residual abutment pressure in the dip direction in the rear of the working face, and the phase of abutment pressure in front of the lower working face.

(2) Gob-side entry retaining in fully mechanized caving is also affected by mining superposition, and roadway deformation is further exacerbated with the progress of the lower working face. To ensure that the entry retaining structure satisfies production requirements at the lower working face, roadway surrounding rock at the roadway development phase and during mining of the upper section should be monitored and the support structure at the entry retaining phase should be reinforced.

(3) A 'long/short anchor cable plus bolt plus net' coupling support method provides excellent support for roadways with fractured roofs. The bolts reinforce a fractured roof, forming a 'composite beam' which is suspended by a long anchor cable in the competent main roof, and the short anchor cable increases the support strength.

(4) Roadside support using roof-contact yielding material facilitates benign roadway roof deformation for energy release and improves structural stability. When gob-side entry retaining is implemented in dipping and steeply dipping coal seams, the strength of the roadside support structure must be ensured and effective measures should be taken to enhance the structural integrity and resistance to toppling of the roadside support.

\section{Acknowledgements}

The study presented in this paper was jointly supported by grants from the National Natural Science Foundation of China (grants no. 51379119, 51109124, 51509149, and 41472281), the Specialized Research Fund for the Doctoral Program of Higher Education of China (grant no. 20113718120009), the National Basic Research Program of China (grant no. 2012CB72310401), the Specialized Funds for 'Taishan Scholar' construction of Shandong Province, the Funds for innovative team of Coal Pillar Performance and Overburden Rock Control, and the Fund for Outstanding Young Scientist Research Award of Shandong Province (grant no. BS2011SF016), Key Laboratory of Safety and High-efficiency Coal Mining, Ministry of Education (grant no. JYBSYS2014106), and the international cooperation training projects for excellent teachers in Shandong Province universities.

\section{References}

BAI, J.B., Shen, W.L., Guo, G.L., WANG, X.Y., and Yu, Y. 2015. Roof deformation, failure characteristics, and preventive techniques of gob-side entry driving heading adjacent to the advancing working face. Rock Mechanics and Rock Engineering, vol.48, no. 6. pp. 2447-2458, 2015. doi: 10.1007/s00603-015-0713-2.

Bu, W.K. and MAo, X.B. 2009. Research on effect of fault dip on fault activation and water inrush of coal floor. Chinese Journal of Rock Mechanics and Engineering, vol. 28, no. 2. pp. 386-394.

CHAI, J., Wang, Z.L., and LiU, W.G. 2015. Monitoring movement laws of overlying key strata for coal mining in similar model. Journal of China Coal Society, vol. 40, no. 1. pp. 35 - 41. doi: 10.13225 /j.cnki jccs.2013.1777

CHEN, Y. 2012. Study on stability mechanism of rockmass structure movement and its control in gob-side entry retaining. China University of Mining and Technology, Xuzhou.

Chen, Y., BaI, J.B., Wang, X.Y., MA, S.Q., Xu, Y., BI, T.F., and Yang, H.Q. 2012. Support technology research and application inside roadway of gob side entry retaining. Journal of China Coal Society, vol. 37, no. 6. pp. 903-910.

CHENG, Z.H., QI, Q.X., and HoNG, Y. 2016. Evolution of the superimposed mining induced stress-fissure field under extracting of close distance coal seam group. Journal of China Coal Society, vol. 41, no. 2. pp. 367-375. doi:10.13225/ j.cnki.jccs.2014.15903-4

CoRnelia, S.H. and MARCEL, N.G.B. 2003. Fiber Bragg grating strain measurements in comparison with additional techniques for rock mechanical testing. IEEE Sensor Journal, vol. 12. pp. 50-55. 


\section{Experimental study on the stability of surrounding soft rocks of gob-side entry}

Deng, Y.H., TAng, J.X., Zhu, X.K., Yong, F., and Hu, H. 2011. Industrial test of concrete packing for gob-side entry retained in gently inclined mediumthickness coal seam. Journal of Southwest Jiaotong University, vol. 46, no. 3. pp. 523-528.

Deng, Y.H. AND WANG, S.Q. 2014. Feasibility analysis of gob-side entry retaining on a working face in a steep coal seam. International Journal of Rock Mechanics and Mining Sciences, vol. 24, no. 4. pp. 499-503.

FAn, Z.Z., MAo, D.B., and Xu, G. 2016. Analysis on the scale effect in the fully mechanized mining panel width with large mining height and dip angle. Journal of China Coal Society, vol. 41, no. 3. pp.581-585. doi: 10.13225/j.cnki.jccs.2015.0589

Franciss, F.O. 1997. Weak Rock Tunneling, Balkema, Rotterdam, The Netherlands.

Ministry of Housing and Urban-Rural Development of the People's Republic of CHINA. 2010.GB50010-2010 Code for Design of Concrete Structures, China Architecture \& Building Press, Beijing.

Gong, P.L., Hu, Y.Q., and ZHAo, Y.S. 2005. Three-dimensional simulation study on law of deformation and breakage of coal floor on mining above aquifer. Chinese Journal of Rock Mechanics and Engineering, vol. 24, no. 3. pp. 4396-4401.

Gu, D.Z. 1995. Equivalent Material and Similar Models. China University of Mining and Technology Press, Xuzhou. pp. 6-56.

Han, C.L., Zhang, N., Li, B.Y., Si, G.Y., and Zheng, X.G. 2015. Pressure relief and structure stability mechanism of hard roof for gob-side entry retaining. Journal of Central South University, vol. 22, no. 11. pp. 4445-4455. doi: 10.1007/s11771-015-2992-X

LI, H.C. 1988, The Similitude Material Model Test on the Rock Pressure. China University of Mining and Technology Press, Xuzhou. pp. 1-2.

Li, X.H., Ju, M.H., Yao, Q.L., Zhou, J., and Chong, Z.H. 2016. Numerical investigation of the effect of the location of critical rock block fracture on crack evolution in a gob-side filling wall. Rock Mechanics and Rock Engineering, vol.49, no. 3. pp. 1041-1058. doi: 101007/s00603-015$0783-1$

LI, J.P. 2005. Study on the technology of gob-side entry retaining with longwall top coal caving system and its application in Lu'an mining district. China Coal Research Institute, Bingjing.

LIU, F.M., CAI, Q.X., and ZHou, W. 2015. Experimental study on the rainfall infiltration rule in the dump slope of surface mines. Journal of China Coal Society, vol. 40, no. 7. pp. 1534-1540. doi: 10.13225/j.cnki.jccs.2015.0100

Luo, S.H., Wu, Y.P., and Liv, K.Z. 2016. Study on the shape of the space stress arch shell in steeply dipping coal seam mining. Journal of China Coal Society, vol. 41, no. 12. pp. 2993-2998. doi: 10.13225/j.cnki.jccs.2016.0539.

MA, L.Q. and ZHANG, D.S. 2004. Industrial test of road-in packing for gob-side entry retaining in fully-mechanized coalface with top-coal caving. Journal of China University of Mining \& Technology, vol. 33, no. 6. pp. 54-58.

MA, L.Q., ZhANG, D.S., CHEN, T., and FAN, G.W. 2007. "Study on packing body supporting resistance of enter-in packing for in-situ gob-side entry retaining in fully-mechanized top-coal caving mining face. Chinese Journal of Rock Mechanics and Engineering, vol. 26, no. 3. pp. 544-550.

MHURC-PRC (Ministry of Housing and Urban-Rural Construction of the People's. Republic of China). 2010. GB 50010-2010. Code for Design of Concrete Structures. https://www.chinesestandard.net/PDFExcerpt/ShowPDFExcerpt.aspx?ExcerptID=GB\%2050010-2010

QIAN, M.G., IsNARD, A.M., XI,- M.B., and Brezhnev, L. 1958. Research of pressure used by similar material simulation method. Journal of Beijing Institute of Mining, vol. 14, no. 1. pp. 28-48.

Ren, S., Guo, S.T., JiAnG, D.Y., and YANG, C.H. 2011. Study of creep similar model and creep equivalent material of salt rock. Rock and Soil Mechanics, vol. 32, no. 1. pp. 106-110.

SHI, X.Q., ZHANG, Z.Q., and LI, H.Y. 2011. Experimental study of prereinforcement technology for weak surrounding rock of tunnel. Chinese Journal of Rock Mechanics and Engineering, vol. 30, no. 9. pp. 1803-1809.

Su, Q.Z. and HAo, H.J. 2002. Modeling of support resistance in roadside packing for retaining entry along gob-side. Coal Mining Technology, vol. 7, no. 4. pp. 32-35.

TAN, Y.L., YU, F.H., Ning, J.G., and ZHAO, T.B. 2015. Design and construction of entry retaining wall along a gob side under hard roof stratum. International Journal of Rock Mechanics and Mining Sciences, vol. 77. pp. 115-121. doi: 10.1016/j.ijrmms.2015.03.025
ITASCA. 2009. FLAC3D-Fast Lagrangian Analysis of Continua.4th edn. Itasca Consulting Group Inc.. Minneapolis, MN.

WANG, H., ZHANG, P.S., and WANG, M.H. 2015. Numerical study on the stability of surrounding rock of gob-side entry retaining along the fully mechanized working face in inclined seam. China Science Paper, vol. 10, no. 21. pp. 2568-2573.

WANG, J.A., ZHANG, J.W., and GAO, X.M. 2015. Fracture mode and evolution of main roof stratum above longwall fully mechanized top coal caving in steeply inclined thick coal seam (I) - initial fracture. Journal of China Coal Society, vol. 40, no. 6. pp. 1353-1360. doi: 10.13225/j.cnki.jccs.2015.0407

WANG, W.J., Hou, C.J., BAI, J.B., and LI, X.H. 2001. Mechanical deformation analysis and principle of floor heave of roadway driving gob in fully mechanized sub-level caving face. Rock and Soil Mechanics, vol. 22, no. 3. pp. 319-322.

WU,Y.P., XIE, P.S., and WANG, H.W. 2010. Incline masonry structure around the coal face of steeply dipping seam mining. Journal of China Coal Society, vol. 35, no. 8. pp. 1252-1256.

Xu, H.Y. and WANG, Y. 2015. Similar simulation study on moving rule of surrounding rock of gob-side entry retaining at fully mechanized caving face. Coal Technology, vol. 34, no. 8. pp. 73-75.

YANG, H.Y., CAO, S.G., LI, Y., Sun, C.M., and Guo, P. 2015. Soft roof failure mechanism and supporting method for gob-side entry retaining. Minerals, vol. 5, no. 4. pp. 707-722. doi: 10.3390/min5040519

YANG, H.Y., CAO, S.G., WANG, S.Q., FAN, Y.C., WANG, S., and ChEN, X.Z. 2016. Adaptation assessment of gob-side entry retaining based on geological factors. Engineering Geology, vol. 209. pp. 143-151. doi: 10.1016/j.enggeo.2016.05.016

YANG, Y.W., BHALLA, S., and WANG, C. 2007. Monitoring of rocks using smart sensors. Tunneling and Underground Space Technology, vol. 22. pp. 206-221.

YAO, Q., FenG, T., and Liao, Z. 2017. Damage characteristics and movement of inclined strata with sublevel filling along the strike in the steep seam. Journal of China Coal Society, vol. 42, no. 12. pp. 3096-3105. doi: 10.13225/j.cnki jccs.2017.0509

Yao, Q., Feng, T., WANG, W.J., Liao, Z., and MA, C.F. 2017. On preparing the materials as close as possible in the experimental ratio and mechanical properties with those gained from mining. Journal of Safety and Environment, vol. 17, no. 6. pp. 2129-2134.

ZHANG, D.S., MAo, X.B., and MA, W.D. 2002. Testing study on deformation features of surrounding rocks of gob-side entry retaining in fullymechanized coal face with top-coal caving. Chinese Journal of Rock Mechanics and Engineering, vol. 21, no. 3. pp. 331-334.

ZHANG, J.Y. 1999. Study on 3D finite element method simulation of strip mining of great inclined and multiple coal seams. Journal of China Coal Society, vol. 24, no. 3. pp. 242-246.

ZHANG, P.S. and Lin, D.C. 2014. Technology of the Retaining Gob-Side Entry China University of Mining and Technology Press, Xuzhou. pp. 10-27.

Zhang, P.S., Kan Z.H., LI, K., Zhao, S.J., Miao, W. WU, S.X., Zhao, Y.P., and WANG, J.W. 2016c. A novel concrete precast block auto-lock entity wall. Chinese patent ZL201520901992.5. 22 June 2016.

ZhANG, P.S., KAn, Z.H., WANG, M.H., ZHAo, S.J., LI, K., and MiAo, W. 2016 a. Numerical study on the stability of surrounding rock of gob-side entry retaining along the fully mechanized working face in inclined seam. Safety in Coal Mines, vol. 47, no. 8. pp. 37-44.

Zhang, P.S., YAN, W., ZhANG, W.Q., SHEn, B.T., and WANG, H. $2016 \mathrm{~b}$. Mechanism of water inrush due to damage of floor and fault activation induced by mining coal seam with fault defects under fluid-solid coupling mode. Chinese Journal of Geotechnical Engineering, vol. 38, no. 5. pp. 877-889.

Zhang, Y.Q., TANG, J.X., XIAO, D.Q., Sun, L.L., and Zhang, W.Z. 2014. Spontaneous caving and gob-side entry retaining of thin seam with large inclined angle. International Journal of Rock Mechanics and Mining Sciences, vol. 24, no. 4. pp. 441-445.

ZhANG, Z.Z., BAI, J.B., CHEN, Y., and YAN, S. 2015. An innovative approach for gob-side entry retaining in highly gassy fully-mechanized longwall topcoal caving. International Journal of Rock Mechanics and Mining Sciences, vol. 80. pp. 1-11. doi: 10.1016/j.ijrmmis.2015.09.001

ZHAO, Y. and ZHANG, Z.G. 2015. Mechanical response features and failure process of soft surrounding rock around deeply buried three-centered arch tunnel. Journal of Central South University, vol. 22, no. 10. pp. 4064-4073. doi: 10.1007/s11771-015-2951-6 